\author{
ANETA JUDZIŃSKA \\ Uniwersytet im. Adama Mickiewicza \\ w Poznaniu
}

\title{
CESARSKA KOBIECOŚĆ MONARCHII NADDUNAJSKIEJ - W CIENIU BALANSUJĄCEJ KONTROLI. STUDIUM PSYCHOSPOŁECZNE
}

\begin{abstract}
Judzińska Aneta, Cesarska kobiecość monarchii naddunajskiej - w cieniu balansującej kontroli. Studium psychospołeczne [Imperial Womanhood of the Danubian Monarchy - Keeping on the Edge of Control. A Psychosocial Study]. Studia Edukacyjne nr 36, 2015, Poznań 2015, pp. 113-130. Adam Mickiewicz University Press. ISBN 978-83-232-2958-2. ISSN 1233-6688. DOI: 10.14746/se.2015.36.7
\end{abstract}

The aim of this article is to deconstruct images of empresses (archduchesses) from the HabsburgLorraine dynasty, currently present in the pop culture. The author makes her own psychological and sociological analyses (including a gender studies viewpoint) of these historical heroines, using contemporary historical studies as well as pop cultural and popular science publications from the turn of the 19th and 20th century. The main focus here lies on the biographies of two women - Maria Theresa of Habsburg and Elizabeth of Austria (Elizabeth Amalie Eugenie von Wittelsbach) who made an (un)conscious effort to achieve independence, perceived here in the context of regaining even if to a limited extent - a sense of control and agency.

Key words: sense of control, imperial motherhood, courtly etiquette, Maria Theresa of Habsburg, Elizabeth Amalie Eugenie von Wittelsbach (Empress Sisi)

Zachowanie jednostki może być sterowane przez czynniki zewnętrzne lub(i) kontrolowane przez nią samą. W pierwszym przypadku mamy do czynienia z osobą zależną od otoczenia, z kimś, kto jest kierowany przez innych ludzi (...) W drugim przypadku człowiek-podmiot sam decyduje o własnym postępowaniu1.

W prowadzonych przeze mnie rozważaniach kategorie poczucia kontroli i sprawstwa zyskują wymiar o tyle istotny, ponieważ dotyczą kobiet wyjąt-

${ }^{1}$ W. Poznaniak, Teorie uczenia się społecznego jako model normalnego i zaburzonego funkcjonowania jednostki oraz grupy, [w:] Społeczna psychologia kliniczna, red. H. Sęk, Warszawa 2000, s. 84. 
kowych, wobec których precyzyjnie wyznaczony habitus, niczym idealnie skrojona suknia miał (wy)tworzyć nową poświatę istnienia, z którą powinny były się identyfikować - często kosztem „deformacji rozwoju indywidualności"2. Wynikało to bowiem z kształtu rzeczywistości społecznej, w której "'jednostka' nie istniała, a indywidualność nie była w cenie" ${ }^{3}$. Nieprzypadkowo więc zredefiniowałam okres, interesujący zarówno w kontekście historycznym (20 października 1740 roku umiera ostatni męski potomek dynastii habsburskiej - Karol VI ${ }^{4}$ i od tej pory powstaje dynastia nowa - habsburskolotaryńska: 1740-19185), jak i społeczno-kulturowym. Spadkobierczynią ogromnej dynastii i zarazem jej niekoronowaną cesarzową staje się kobieta: Maria Teresa Habsburg (córka Karola VI, panująca w latach 1740-17806). Ta „austriacka caryca” daje początek nowej europejskiej potędze, stając się tym samym jej pramatką i założycielką. Szczególnie interesujący - w kontekście cesarskiej kobiecości - wydaje się proces adaptacji do nowej, ściśle określonej roli, jaka w spektaklu cesarskiego życia odgrywana była pod okiem "czujnego reżysera" - dworskiego ceremoniału. Prawdopodobną jej konsekwencją było "tożsamościowe spętanie", które w mniejszym lub większym stopniu mogło wygenerować potrzebę odzyskania - za pomocą zróżnicowanych działań - poczucia sprawstwa nad własnym życiem. Problem „balansującej kontroli"7 staje się szczególnie czytelny w przypadku dwóch kobiet-cesarzowych: Marii Teresy Habsburg oraz Elżbiety Amalii Eugenii von Wittelsbach ${ }^{8}$, co skłania mnie do głębszego przeanalizowania ich biografii.

Pragnę jednocześnie zaznaczyć, że niniejszy artykuł nie aspiruje do miana pracy historycznej. Dokonuję w nim własnych psychologicznych i socjologicznych (z uwzględnieniem perspektywy gender) analiz wizerunku bohaterek zarówno na podstawie współczesnych opracowań historycznych, jak i materiałów publicystycznych, popularnonaukowych oraz popkulturowych przełomu XIX/XX wieku. Kontekstualna oraz gatunkowa różnorodność literatury pozwala, według mnie, w sposób dyskursywny uchwycić specyfikę rzeczywistości kulturowej, w której funkcjonowały cesarzowe. Doskonale obrazuje także sposób ich społecznego odbioru, jak również au-

2 E. Fromm, Ucieczka od wolności, Warszawa 1999, s. 140.

${ }^{3}$ A. Giddens, Nowoczesność i tożsamość, Warszawa 2010, s. 107.

${ }^{4}$ H. Andics, Kobiety Habsburgów, Wrocław 1991, s. 131.

5 Tamże, s. 324-325.

6 1717-1780, żona współregenta, późniejszego cesarza Franciszka I Stefana Lotaryńskiego, arcyksiężna Austrii, królowa Węgier i Czech (tamże, s. 324).

7 Kontrola posiada $\mathrm{w}$ tym ujęciu charakter procesualny, nigdy nie jest odzyskana raz na zawsze, wykazuje niezwykłą wrażliwość na warunki społeczno-kulturowe.

8 1837-1898, żona Franciszka Józefa, cesarzowa Austrii, królowa Węgier i Czech panująca w latach 1854-1898 (B. Hamann, Cesarzowa Elżbieta, Warszawa 1999, s. 5, 11-12). 
tokoncepcji odzwierciedlającej się chociażby w ich twórczości literackiej (przykład Elżbiety Wittelsbach). Moim celem jest zatem dekonstrukcja popkulturowych wizerunków "cesarskiej kobiecości” z uwzględnieniem koncepcji płci kulturowej, którą postrzegam (za A. Titkow) jako

odrzucenie kategorycznej opozycji męskość - kobiecość i zarazem odrzucenie postawy ignorowania istniejącej biologicznej różnicy. [Płeć kulturowa - przyp. A.J.] to również przekonanie, że to, co jest traktowane jako biologiczna różnica, jest w znaczącym stopniu efektem procesów kulturowych ${ }^{9}$

zmieniających się na przestrzeni wieków, lat.

Choć zadaniem niezwykle trudnym jest podjęcie próby skonfrontowania współczesnych teorii naukowych (np. z dziedziny psychologii czy socjologii) i odpowiadających im standardów życia społecznego z całkowicie odmienną specyfiką egzystencji kobiet-cesarzowych przełomu XVIII/XIX wie$\mathrm{ku}$ (nakreślonych surowymi standardami roli społecznej, którą realizowały), postaram się uchwycić fenomen ponadepokowej walki kobiet o własną tożsamość.

\section{Cesarskie macierzyństwo \\ - kontrowersje wokół uprzedmiotowionej podmiotowości}

Podejmując refleksję nad kategorią poczucia kontroli i sprawstwa cesarzowych, warto uprzednio odwołać się do podstawowego, dworskiego imperatywu wyznaczającego standardy prawidłowo zrealizowanej roli. Trzeba zatem podkreślić, że pozycja kobiet na cesarskich dworach określona była zdolnościami (czy wręcz możliwościami) reprodukcyjnymi. Podyktowany ustrojem monarchii absolutnej dogmat macierzyństwa stanowił najważniejszy element tożsamości kobiety (wpisując się poniekąd w treść dworskiego ceremoniału). Można zatem wysunąć przypuszczenie, że dynamika procesu upodmiotowienia austriackich cesarzowych (bądź arcyksiężniczek) z dynastii habsbursko-lotaryńskiej (i nie tylko ich) podlegała fundamentalnemu kryterium - imperatywowi macierzyństwa. Przy czym, co warto podkreślić, mogła się ona urzeczywistnić i dopełnić jedynie poprzez wydanie na świat potomka płci męskiej. Urodzenie chłopca, pretendenta do cesarskiej korony, stanowiło zarówno atrybut, jak i fundamentalny warunek zrealizowania

9 A. Titkow, Kategoria płci kulturowej jako instrumentarium badawcze i źródło wiedzy o społeczeństwie, [w:] Gender w społeczeństwie polskim, red. K. Slany, J. Struzik, K. Wojnicka, Kraków 2011, s. 38 . 
cesarskiej kobiecości10 (spełnienia oczekiwań formułowanych wobec żony cesarza - cesarzowej ${ }^{11}$ ). Bowiem cesarzowa „bez dziecka, bez syna nie miała dla cesarza, dworu i państwa żadnego znaczenia"12. Jeżeli ów cel nie mógł być osiągnięty, podejmowano wobec przyszłej matki zróżnicowane (niekiedy bardzo kontrowersyjne) kuracje medyczne, które w ostateczności miały doprowadzić do szczęśliwego rozwiązania. Przekonała się o tym matka Marii Teresy, Elżbieta Krystyna z Brunszwiku-Wolfenbüttel ${ }^{13}$, którą po trzech latach bezowocnego $\mathrm{w}$ potomstwo małżeństwa poddano słynnej w ówczesnym środowisku wiedeńskim terapii winem (Weintherapie). To dość kontrowersyjne, zalecane przez medyków lekarstwo (Weinkur) nierzadko stawało się przyczyną innej choroby - alkoholizmu ${ }^{14}$. W przypadku Elżbiety Krystyny - mimo bezustannie zwiększanej dawki owego „medykamentu” nie uzyskano oczekiwanych rezultatów (pierwsze dziecko urodziła 5 lat później, od momentu wdrożenia tej terapii). Jedyna doświadczalna zmiana, którą mogą zaobserwować również potomni, spoglądając na portret cesarzowej umieszczony $\mathrm{w}$ jednej $\mathrm{z}$ komnat pałacu Schönbrunn, to ocieplające porcelanową twarz "intensywne” rumieńcie. Jak "subtelnie” ujmuje to H. Andics, w wyniku Weinterapie ,jej twarz nabrała tej różowej barwy, jaką można zaobserwować u nałogowych alkoholików"15.

Macierzyństwo będące valde optandum est (sprawą wielce pożądaną) stanowiło zatem podstawowy wyznacznik samooceny, poczucia własnej wartości wynikających ze zrealizowania swojej najważniejszej życiowej roli matki. Pragnę tym samym podkreślić, jak szczególnie znamienny i bezprecedensowo deterministyczny był pierwotny przekaz socjalizacyjny formułowany wobec młodych księżniczek aspirujących - na podstawie swojej genealogii - do roli przyszłej małżonki (bądź przy odrobinie szczęścia - matki) cesarza. Młodą damę zazwyczaj

wychowywano tak, aby stale myślała o tym, że nie należy do samej siebie, lecz do państwa, czy też do dynastii, co zresztą w świecie, w którym żyła, znaczyło jedno i to samo'16.

${ }^{10}$ L. Fischer, Schattenwürfe in die Zukunft: Kaiserin Elisabeth und die Frauen ihrer Zeit, Wien 1998, s. 29.

11 Wyjątek stanowi tutaj żona arcyksięcia, pretendenta do korony cesarskiej Franciszka Ferdynanda, Sophie Chotek, która z powodu ograniczeń genealogicznych nie mogła aspirować do roli i przywilejów przyszłej cesarzowej (G. King, S. Woolmans, Zabić arcyksięcia, Kraków 2014, s. 108).

12 H. Andics, Kobiety Habsburgów, s. 172.

13 1691-1750, żona cesarza Karola VI, cesarzowa Austrii, królowa Węgier i Czech, panująca w okresie 1711-1740 (tamże, s. 124, 129).

${ }_{14}$ H. Bankl, Die kranken Habsburger. Befunde und Befindlichkeiten einer Herrscherdynastie, Wien 1998, s. 49.

${ }^{15}$ H. Andics, Kobiety Habsburgów, s. 124.

16 Tamże, s. 174. 
Uwypuklające się kontrowersje wobec kobiecej podmiotowości uwarunkowanej rygorystycznymi oczekiwaniami reprodukcyjnymi doskonale wpisują się $\mathrm{w}$ problematykę zawłaszczenia ludzkiego ciała w ujęciu Michela Foucalt. Jak słusznie konstatuje XX-wieczny socjolog,

ciało zanurzone jest (...) bezpośrednio w sferze polityki, stosunki władzy wpływają na nie wprost: blokują je, naznaczają i urabiają, torturują, zmuszają do rozmaitych prac, różnych obrzędów, domagają się odeń znaków (...) Zasadniczo ciało jest blokowane relacjami władzy i dominacji jako siła produkcyjna, ale sprowadzenie go do siły roboczej jest możliwe nie wcześniej, nim zostanie włączone w system ujarzmienia (...) Jego siła staje się pożyteczna dopiero wówczas, kiedy będzie ciałem produktywnym i ujarzmionym zarazem ${ }^{17}$.

Stosując analogię wobec cesarzowych, można zauważyć że ich ciało stanowiło podstawowy aparat opresji i zniewolenia. Z chwilą zawarcia „cesarskiego" małżeństwa (ujarzmienia), traciło ONO (w sposób symboliczny) możliwość decydowania o sobie i stawało się własnością złożonego systemu politycznego. Zaczynało wówczas podlegać bezwarunkowo nieugiętym zasadom dynastycznych oczekiwań. Uwikłane w kategorie władzy i dominacji posłusznie poddawało się procesom urabiania (pojmowanym tutaj w kontekście wiodącego imperatywu macierzyństwa). Realizując swoją fundamentalną reprodukcyjną rolę $\mathrm{w}$ postaci wydania na świat kolejnego potomka (owego „znaku”), stawało się - z racji swojej produktywności - chwilowo tylko podmiotem, po czym pospiesznie "wracało" do swego pierwotnego, przedmiotowego stanu (aż do momentu urodzenia kolejnego dziecka). Podstawowy paradoks tkwił, według mnie, nie w samym macierzyństwie (daleka jestem od koncepcji ujmujących macierzyństwo w kategoriach zniewolenia), lecz w specyficznie zawężonym sposobie jego konceptualizacji, pozbawiającym kobietę współdecydowania o poczęciu dziecka czy swobodnym dostępie do jego sfery emocjonalnej oraz wszelkich oddziaływań wychowawczych. Powyższy problem doskonale eksponuje H. Andics, zdaniem którego

najbardziej lubiła habsburska polityka rodzinna - [by kobieta była - przyp. A.J.] godną zaufania matką hodowlaną, która $\mathrm{z}$ jednego połogu przechodziła $\mathrm{w}$ drugi, a poza tym wszystko, włącznie $\mathrm{z}$ wychowaniem dzieci, pozostawiała instancjom dworskim i strzeżonym przez nie pilnie tradycjom ceremoniału dworskiego ${ }^{18}$.

Można więc wysunąć wniosek, że ów ceremoniał niezwykle ekspansywnie ingerował $\mathrm{w}$ pozbawioną prywatności przestrzeń życia cesarzowych,

17 M. Foucault, Nadzorować i karać. Narodziny więzienia, Warszawa 1993, s. 32.

${ }^{18}$ H. Andics, Kobiety Habsburgów, s. 172. 
marginalizując inne - kluczowe dla rozwoju - płaszczyzny aktywności. Dotyczy to szczególnie obszaru edukacji, zredukowanej do - wyznaczanych przez surową etykietę - „ascetycznych" standardów nauczania młodych księżniczek. Doskonałą egzemplifikację deprecjonowania kompetencji intelektualnych stanowi przypadek Izabelli Marii Burbon-Parmeńskiej19, żony cesarza Józefa II ${ }^{20}$ (syna Marii Teresy), której wskazywana przez badaczy erudycja nie zdołała zniwelować "reprodukcyjnej skazy” (wydała ona na świat dwie córki, które umarły po kilku latach życia).

Inteligentna i piękna, umiała gromadzić wokół siebie znakomitych ludzi, jak córka Neckera madame de Staël czy sam Johann Wolfgang von Goethe. Nie tego jednak oczekiwano po cesarzowej; nie pomnożyła dynastii21.

Restrykcyjny ceremoniał dworski (szczególnie względem kobiet) stał się przedmiotem krytyki XIX-wiecznej niemieckiej pisarki Luise Mühlbach (a właściwie Clary Müller-Mundt). W zabarwionej nutą feministyczną powieści historycznej Kaiser Joseph der Zweite und sein Hof. Historischer Roman uwypukla ona w sposób ironiczny absurdy dworskiego życia. Możemy to odczytać z wypowiedzi żony głównego bohatera, wspomnianej powyżej Izabeli Marii Burbon-Parmeńskiej, która żartobliwie nadmienia o wszechobecnej etykiecie, bezwzględnie ingerującej w kształt cesarskiej codzienności:

Mój panie i mężu - powiedziała, śmiejąc się - mimo że Wasza Cesarska Wysokość wygnała Madame Etykietę z naszego balkonu, pamiętaj, że ona nadal stoi tam i czeka na nas z groźną miną, u tamtych drzwi, i że musimy zabrać ją ze sobą, przed oblicze naszej dostojnej Cesarzowej. Madame Etykieta w życiu nie pozwoliłaby mi przybyć $\mathrm{w}$ tak skromnej sukni. Wzburzona, kazałaby mi zejść sobie z oczu, i Waszej Wysokości również. Idź zatem, i przywdziej swe najstrojniejsze hiszpańskie szaty. Oczekuję Waszej Wysokości w tym miejscu w ciągu kwadransa22.

Podejmując refleksję nad kształtem cesarskiego macierzyństwa, chciałabym zwrócić uwagę na jeszcze jeden jego kontekst. Mianowicie, w przypadku niektórych arcyksiężniczek stanowiło ono podstawowy kanał ruchliwości społecznej23, zbliżając je tym samym do przejęcia władzy (kontroli) nad

19 1741-1763, pierwsza żona Józefa II Habsburga, arcyksiężna Austrii w latach 1760-1763 (tamże, s. 144, 148-150).

20 1741-1790, arcyksiążę Austrii, cesarz rzymski panujący w latach 1765-1790 (tamże, s. 143,324$)$.

${ }^{21}$ S. Grodziski, Habsburgowie. Dzieje dynastii, Wrocław 1998, s. 145.

${ }^{22}$ L. Mühlbach, Joseph II. And his Cort. An Historical Novel, przekł. A. DeV. Chaudron, New York 1867, s. 33.

${ }^{23}$ Por. A. Gromkowska-Melosik, Edukacja i (nie)równość spoteczna kobiet: studium dynamiki dostępu, Kraków 2011, s. 24. 
państwem. Stało się tak w przypadku Zofii Wittelsbach ${ }^{24}$ - „kobiety z temperamentem, bystrym rozumem i silną wolą"25, za sprawą której jej wątly intelektualnie mąż Franciszek Karol zrezygnował z przyjęcia cesarskiej godności na rzecz swojego syna Franciszka Józefa26. „Zofia miała opinię 'jedynego mężczyzny' na pełnym słabeuszy dworze (...) a w latach pięćdziesiątych była niekoronowaną cesarzową Austrii", która zarządzała państwem $\mathrm{z}$ ramienia swojego ukochanego syna ${ }^{27}$.

Bez względu jednak na motywy, które kierowały zachowaniem arcyksiężniczek/cesarzowych, można wysunąć przypuszczenie, że precyzyjnie określony dworski ceremoniał i stanowiący jego trzon imperatyw (ograniczonego) macierzyństwa tworzyły podstawowy konglomerat represjonujący poczucie kontroli i sprawstwa cesarzowych.

\section{Maria Teresa Habsburg}

Pojęcie kontroli wydaje się być permanentnie wpis(yw)ane w ewoluującą tożsamość Marii Teresy. Niewątpliwie istotną rolę odegrało tutaj urzędowe „uprawianie” władzy sensu stricto, której kontrola stanowiła istotny atrybut. Jednakże, jej przejawy widoczne były, w moim przekonaniu, również na płaszczyźnie życia rodzinnego. Wychowanie dzieci - zadanie od stuleci powierzane dworskim instancjom - także stało się przedmiotem jej oddziaływań. Jak wskazuje S. Grodziski, Maria Teresa

wychowywała [swoje dzieci - przyp. A.J.] surowo, choć z pewną szczególną, szorstką dbałością o ubranie; nie pozostawiała tych spraw wyłącznie dworskim guwernantkom i nauczycielom, osobiście je kontrolując ${ }^{28}$.

Owa „matczyna troska” wzbogacona wymierną dozą cesarskiej dyrektywności wydawała się niewrażliwa na upływający czas. Doskonałe jej odzwierciedlenie stanowił precedens aranżowanych małżeństw, którego koordynatorka - Maria Teresa występowała w dwóch, przenikających się wzajemnie, rolach: matki i władczyni. Realizując dynastyczno-polityczne

24 1830-1916, cesarz Austrii, król Czech i Węgier panujący w latach 1848-1916 (H. Andics, Kobiety Habsburgów, s. 324-325).

25 Tamże, s. 172.

${ }^{26}$ E. Bechmann, Die Frauen der Wittelsbacher: Ein Frauenbild vom Mittelalter bis in die Gegenwart, Norderstedt 2014, s. 62-63.

27 B. Hamann, Cesarzowa Elżbieta, s. 21.

${ }^{28}$ S. Grodziski, Habsburgowie. Dzieje dynastii, s. 97. 
cele, sprawowała jednocześnie pieczę nad swoimi dziećmi ${ }^{29}$. Kategorie kontroli i poczucia sprawstwa wpisują się również w sferę "rozluźnionych" relacji małżeńskich (wywołanych, słabością jej męża względem kobiet ${ }^{30}$ ) przyjmując formę - jak przypuszczają niektórzy badacze - upolitycznionej rewizji żeńskiej części cesarstwa. Zniesmaczona rozwiązłym życiem zarówno arystokracji, jak i niższych warstw społecznych (bądź przede wszystkim - jak podają niektóre źródła - rozwiązłością seksualną męża ${ }^{31}$ ) powołała słynną w całej ówczesnej Europie, komisję czystości obyczajów i wychowania (Keuschheitskommission), która swoim zasięgiem obejmowała nie tylko cesarski Wiedeń, ale też inne większe miasta monarchii. Jednocześnie należy podkreślić, że winę dostrzegała wyłącznie w rozpustnych kobietach. Represje wobec owych „lubieżnic" nierzadko w konsekwencji przyczyniały się do przyjmowania standardów tzw. podwójnej moralności ${ }^{32}$. Kuriozum sytuacji doskonale egzemplifikuje fragment arii ze słynnej operetki "Zemsta Nietoperza" Johana Straussa (powstałej ponad 100 lat później):

„W roli skromnego dziewczęcia,

Skromnego, lecz owszem do wzięcia,

Rumienię się, buzię mam w ciup,

Cnotliwa od kolan do stóp" 33 .

Niezwykle surowy stosunek Marii Teresy względem kobiet można również wyczytać z jej poglądów na temat oddziaływań wychowawczych, bo „choć sama pełniła najwyższą funkcję w państwie, uważała, iż kobiety winny być podporządkowane mężczyznom i w tym kierunku iść winna ich edukacja" 34 . Pozostawało to w pewnej sprzeczności względem kształtu jej życia, które wprawdzie od czasów dzieciństwa naznaczone było opartą na zasadzie binaryzmu płci tradycyjną socjalizacją, gdzie „otrzymała [ona przyp. A.J.] surowe wychowanie na skrępowanym hiszpańską etykietą dworze swego ojca Karola VI, [lecz jednak - przyp. A.J.] nie zgasiło to jej temperamentu" 35 i nie przeszkodziło w sprawowaniu „zmaskulinizowanej władzy". Uwypuklające się w działaniach cesarzowej tradycyjne spojrzenie

${ }^{29}$ Tamże, s. 106-109.

${ }^{30}$ Franciszek I Stefan przejawiał niezwykłą słabość wobec płci przeciwnej, czego dowodem był jego długoletni seksualny związek z hrabiną Wilhelminą Auersperg (H. Andics, Kobiety Habsburgów, s. 140).

31 Tamże, s. 141.

32 S. Grodziski, Habsburgowie. Dzieje dynastii, s. 98.

33 J. Strauss, Zemsta Nietoperza, „Kuplety Adeli” - akt III.

${ }^{34}$ S. Grodziski, Habsburgowie. Dzieje dynastii, s. 97.

${ }^{35}$ H. Andics, Kobiety Habsburgów, s. 97. 
na kwestie kobiecości (wynikające zapewne ze specyfiki czasów, w których przyszło jej żyć36), współwystępujące z przejęciem przez nią męskich standardów zarządzania, stanowi pewną analogię wobec współczesnego problemu zawodowego kobiet, zwanego syndromem królowej pszczół. Postrzegany jako „świadome przyjęcie męskiej tożsamości i odrzucenie cech tradycyjnej tożsamości kobiecej"37, wzmacniany był w przypadku Marii Teresy partycypacją w środowisku wyłącznie męskich doradców. Należy przy tym zaznaczyć, iż sam fenomen objęcia wielkiego dziedzictwa przez 23-letnią kobietę został sprowadzony do kwestii nieformalnej walki o jego przyjęcie i utrzymanie. Początkowo jako „ofiara własnej płci”, Maria Teresa zogniskowała $\mathrm{w}$ sobie esencjalistyczne spojrzenia politycznych przeciwników, (bezskutecznie!) testujących granice uległości młodej i niedoświadczonej władczyni ${ }^{38}$. Jak podkreślają autorzy monografii Empress Maria Theresa and the Politics of Habsburg Imperial Art,

w systemie monarchicznym nie było parytetu płci, gdyż z definicji królowa miała status zaledwie drugorzędny względem swego męża, króla. Zatem, sam fakt przyjęcia przez Marię Teresę męskiego tytułu królewskiego nie był wystarczającą przesłanką do zabezpieczenia jej władzy ${ }^{39}$.

Szczególnie interesujący z punktu widzenia teorii socjologicznych i feministycznych wydaje się kontekst uroczystości koronacyjnych (np. na Węgrzech), które przebiegały według typowo męskich standardów. Oznacza to, że Maria Teresa zobligowana była do wiernego odzwierciedlenia zachowań swoich poprzedników, włącznie z przejęciem męskich insygniów wojskowej i królewskiej władzy (miecz, płaszcz oraz korona Świętego Stefana pochodzące z XI w.). Spróbujmy zatem wyobrazić sobie młodą kobietę w 700letniej męskiej koronie na głowie, odzianą w długi, obficie zdobiony ornamentami płaszcz koronacyjny, która trzymając w ręku miecz, zmierza konno w stronę Koronacyjnego Wzgórza. Następnie unosi ów miecz do góry, kie-

${ }^{36}$ E. Zamojska, Dążenia emancypacyjne kobiet - równość w dyskursie feministycznym, Pampaedia: Leszczyńskie Studia Humanistyczne, 2004, 1.

37 A. Gromkowska-Melosik, Z. Melosik, Tożsamość w społeczeństwie wspótczesnym: popkulturowe (re)interpretacje, Kraków 2012, s. 84.

38 Szczególnie wtedy, gdy próbowano za wszelką cenę unieważnić postanowienie jej ojca Karola VI dotyczące sankcji pragmatycznej. Tuż po jego śmierci usiłowano wykorzystać brak doświadczenia i młody wiek Marii Teresy, by podstępnie przejąć władzę, jak zaplanował to elektor Karol Albrecht Bawarski, bądź pozbawić cesarstwo austriackie ziem śląskich na rozkaz pruskiego króla Fryderyka - bezskutecznie (H. Andics, Kobiety Habsburgów, s. 138).

${ }^{39}$ M.E. Yonan, Empress Maria Theresa and the Politics of Habsburg Imperial Art, Pensylwania State 2011, s. 28. 
rując go - w akcie metaforycznym - w cztery strony świata, co symbolizować ma ochronę narodu węgierskiego przed atakiem wrogów ${ }^{40}$.

Można więc przypuszczać, że niespecyficzność roli społecznej, „odziedziczonej" na drodze sankcji pragmatycznej cesarzowa harmonizowała pielęgnując w sobie przeświadczenie o boskości swojej władzy - Dei gratia (pochodzącej od Boga) ${ }^{41}$ oraz wierze „w moc czerpaną od symbolicznego przedstawiciela męskiej siły, Świętego Stefana, którego koronę i miecz nosi$\mathrm{ła}^{\prime \prime 4}$. Niewątpliwie, owa autogloryfikacja - niczym samospełniające się proroctwo - pozytywnie korelowała z efektami pracy władczyni, dając (nie)świadomie zamierzony efekt. Jak pisze o Marii Teresie H. Andics:

wydawało się, że skoncentrowała ona w sobie wszystko, co uczyniło Dom Austriacki wielkim w minionych stuleciach: siłę woli, moc ducha i święte przeświadczenie o przywódczej misji dziejowej Domu Austriackiego w świecie zachodnim³.

Najprawdopodobniej owe przymioty spowodowały, że niezwykle zręcznie posługiwała się "językiem władzy" w nadzwyczaj trudnej do zrealizowania misji, przypisanej od wieków mężczyznom ${ }^{44}$. Ośmielę się wysunąc hipotezę, że piastowanie wysoce zmaskulinizowanego stanowiska mogło wywołać nieświadomy (a może świadomy?) płciowy dysonans, narażając ją na zarzut utraty kobiecości. Jako władczyni musiała bowiem sprostać typowo męskim standardom, by efektywnie sprawować najwyższy w cesarstwie urząd (władza miała bowiem charakter wyłącznie męski) ${ }^{45}$. Biologicznie Maria Teresa pozostawała jednak nadal kobietą, wobec której formułowano zupełnie inne oczekiwania. Nie dziwi zatem, że jako cesarzowa (odwołam się tutaj do tradycyjnego charakteru płci kulturowej wszystkich cesarzowych/arcyksiężniczek) starała się przede wszystkim wypełnić swój podstawowy na dworze kobiecy imperatyw, który zrealizowała niemal perfekcyjnie rodząc szesnaścioro dzieci (jedną z jej córek była Maria Antonina, przyszła żona króla Francji Ludwika XVI, która zginęła podczas rewolucji francuskiej) ${ }^{46}$.

40 Tamże, s. 29.

41 S. Grodziski, Habsburgowie. Dzieje dynastii, s. 97.

42 M.E. Yonan, Empress Maria Theresa, s. 29.

${ }^{43}$ H. Andics, Kobiety Habsburgów, s. 138.

${ }^{44}$ M. Bogucka, Gorsza pteć. Kobieta w dziejach Europy od antyku po wiek XXI, Warszawa 2005, s. 185.

45 Por. A. Judzińska, Womanhood - contemporary paradoxes of equality and exclusion, Journal of Gender and Power, 2014, 2(2), s. 141-142.

${ }^{46}$ S. Grodziski, Habsburgowie. Dzieje dynastii, s. 106. 


\section{Elżbieta Amalia Eugenia von Wittelsbach (Sisi)}

Podejmując dyskurs nad kategorią poczucia kontroli i sprawstwa cesarzowych, warto, według mnie, odwołać się do sylwetki Elżbiety Amalii Eugenii von Wittelsbach, księżniczki bawarskiej, cesarzowej Austrii i królowej Węgier, znanej powszechnie jako Sisi. Ta niezwykle barwna szczególnie dla opinii publicznej postać, której zniekształcany romantyzmem i beletrystyczną komercją wizerunek przedstawiają współczesne mass media ${ }^{47}$, doskonale oddaje nakreśloną licznymi antagonizmami specyfikę tragizmu życia cesarzowej. Staje się to szczególnie znamienne, kiedy do analizy włączymy dwa kluczowe aspekty: biologiczny oraz społeczno-kulturowy. Pierwszy odnosi się tutaj do, uwarunkowanych związkami endogamicznymi, zaburzeń genetycznych rzutujących negatywnie na kondycję psychiczną arystokratycznych potomków. Staje się to szczególnie czytelne w przypadku przedstawicieli rodu Wittelsbachów, gdzie wrodzona skłonność do melancholii doprowadzała w konsekwencji większość z nich do pogłębiającej się społecznej izolacji (czego doświadczyła również Elżbieta) ${ }^{48}$. Drugi czynnik związany jest $\mathrm{z}$ "liberalną" socjalizacją, której została w tym przypadku poddana przyszła cesarzowa. Spędzone w sposób dość beztroski - jak na królewską córkę - dzieciństwo, dalekie było od wytwornego towarzystwa i arystokratycznej edukacji. W znakomitej, nieszablonowej ${ }^{49}$ biografii Cesarzowa Elżbieta Brigitte Hamman podkreśla, że

Elżbieta była z natury kobietą o gorącym sercu i miłującą sprawiedliwość. Tak jak jej rodzeństwo, od dziecka była nakłaniana do troski o biednych i chorych. Nie wpojono jej arystokratycznej dumy, znała domy biedaków w okolicy rodzinnej posiadłości Possenhofen ${ }^{50}$.

Zatem możemy przypuszczać, że konfrontacja owładniętej poczuciem swobody bawarskiej, piętnastoletniej księżniczki z chłodną dystynkcją wiedeńskich imperatywów, doprowadziła do kulturowego dysonansu ${ }^{51}$, utrud-

${ }^{47}$ Mam tutaj na myśli przede wszystkim produkcje filmowe, np. trylogię z Romy Schneider wcielającą się w postać cesarzowej Elżbiety, powstałą w latach 1955-1957, czy mini serial „Sisi” z 2009 roku.

${ }^{48}$ Ludwik - król Bawarii, Otto, jego brat, książę Pius - dziadek Sisi (B. Hamann, Cesarzowa Elżbieta, s. 36).

49 Wzbogaconej o dogłębną analizę nieznanych dotąd materiałów źródłowych, w porównaniu z pozostałymi, ukształtowanych pod wpływem biografii sporządzonej przez Egona Cezara Conte Cortiego z 1934 roku, kreślących romantyczny obraz pięknej Sisi.

50 B. Hamann, Cesarzowa Elżbieta, s. 51.

51 Niniejszy termin definiuję jako brak spójności pomiędzy standardami wyznaczonymi przez pierwotne środowisko kulturowe jednostki a oczekiwaniami kierowanymi wobec owej jednostki przez wtórne środowisko kulturowe, w którym partycypuje. 
niając $w$ tym przypadku efektywną internalizację nowej, społecznej (a nawet życiowej) roli. H. Andics posługując się językiem metafory, w interesujący sposób eksponuje problem owego „kulturowego rozdźwięku”, którego doświadczyła Elżbieta przyjmując - na drodze zaślubin - godność cesarskiej małżonki z całym dworskim dobrodziejstwem inwentarza (ocenianym notabene przez autora dość krytycznie).

Było to tak, jakby dzikiego mustanga włączono do zastępu tresowanych koni i oczekiwano natychmiastowego pokazania dobrze wystudiowanego numeru cyrkowego. Dwór wiedeński ze swymi tysiącami urzędników, którzy poruszali się precyzyjnie jak marionetki według ceremoniału ułożonego najdokładniej dla każdego kroku i dla każdego ruchu ręką, był podobny do takiego cyrku, i to dającego codziennie przedstawienie galowe $\mathrm{e}^{52}$.

Jak trafnie konkluduje B. Hamann,

wszystkie te pozytywne cechy, które Sisi wyniosła z nieskrępowanego i pełnego miłości dzieciństwa i które rozwinęły się dzięki jej wrażliwej naturze - okazały się bezwartościowe, ba - nawet przeszkadzały. Ponieważ dwór wiedeński, majestat cesarza i wysoka pozycja rodziny cesarskiej polegały przede wszystkim na protokole i ceremonii, brak arystokratycznej dumy był uważany w Wiedniu nie za zaletę, lecz za skazę, podobnie jak lekceważenie formalności53.

Można więc powiedzieć, że młoda cesarzowa znalazła się na „socjalizacyjnym rozdrożu”, gdyż wychowana została wobec epokowo odmiennych standardów, niewspółmiernych z rzeczywistością, w której przyszło jej żyć. Ów kontrast staje się szczególnie czytelny, kiedy do analizy włączymy doniosłe znaczenie dworskiego protokołu (Hofzeremoniell), który ukształtowany na gruncie $\mathrm{XV}$-wiecznego, hiszpańskiego ceremoniału o „etykiecie związanej z samodycyplinowaniem się do dostojnej mowy, gestów, służalczych manier" 54 , stanowił atrybut arystokratycznej homeostazy. Elżbieta z biegiem lat coraz czytelniej manifestowała swoją dezaprobatę wobec jego licznych, bezkompromisowych standardów. Początkowo przedmiotem frustracji i buntu „wychowanej do samodzielności” cesarzowej stawał się szereg codziennych, rutynowych nakazów (i zakazów zarazem), którym musiała się podporządkować: począwszy od kwestii ubioru (ubierana wyłącznie przez damy dworu, każdą parę butów po jednorazowym użyciu zobowiązana była oddać innym kobietom), ustalenia odpowiedniego menu (protokół nie zezwalał cesarzowej np. na picie jej ulubionego trunku - piwa), a skończyw-

52 H. Andics, Kobiety Habsburgów, s. 194.

53 Tamże, s. 51.

${ }^{54}$ X. Sellés-Ferrando, Spanisches Österreich, Wien 2004, s. 189. 
szy na otoczeniu, w którym powinna była przebywać (damy dworu, wybrane przez jej teściową Zofię, towarzyszyły jej przez cały dzień) ${ }^{55}$. W sposób nad wyraz treściwy uwypukla się tutaj problem utraconej kontroli nad własną egzystencją. Znalazło to swoje odzwierciedlenie w licznych wierszach poświęconych tematyce wolności. Już w 1854 roku - dwa tygodnie od momentu zawarcia cesarskiego małżeństwa - Elżbieta napisała pełen żalu i tęsknoty poemat o wolności, w którym swoje cesarskie życie przyrównuje do więzienia: "Obudziłam się w lochu i kajdany są na moich dłoniach” 56 . Punktem kulminacyjnym „zniewolenia” stał się kształt cesarskiego macierzyństwa, a ściślej jego namiastka, precyzyjnie określająca ograniczone prawa matki-cesarzowej względem córek i syna (Elżbieta z racji swojej pozycji na dworze, nie posiadała takiej władzy jak Maria Teresa i tuż po urodzeniu odbierano jej dzieci). Utracone poczucie kontroli doskonale wyjaśnia w teorii reaktancji J. Brehm zakładając, że „odebranie człowiekowi swobody wyboru działania, myślenia lub odczuwania bądź samo zagrożenie takim odebraniem powoduje stan oporu psychicznego", prowadząc w konsekwencji do reakcji opozycyjnych, buntowniczych ${ }^{57}$. Jednak, w przypadku Elżbiety bariera sztywnej etykiety przypominającej "prawdziwy regulamin musztry, liczący wiele stron” była zbyt silna, by móc ją skutecznie przezwyciężyć za pomocą buntu 58 .

W naturalny sposób nasuwa się więc pytanie: czy bezowocna $\mathrm{w}$ pierwszych latach panowania Elżbiety (w większości przypadków) próba buntu przekształciła się $\mathrm{w}$ inny, sprzyjający odzyskaniu poczucia kontroli mechanizm? Z pewnością nie było nim dążenie do monarszej władzy i politycznej ekspansji (chociaż Elżbieta wykazywała ciągoty republikańskie). Analiza biografii cesarzowej wskazuje raczej na pewne związki z opisywanym przez socjologa R. Mertona fenomenem wycofania, w którym ludzie

zarzucili zalecane cele kulturowe, a ich zachowania nie odpowiadają normom instytucjonalnym (...) Ucieczka jest całkowita, konflikt wyeliminowany, i jednostka staje się człowiekiem odspołecznionym ${ }^{59}$

55 G. Pirntke, Aufstieg und Fall der Kaiserin von Österreich, 2011, https://books. google.pl/books?id=0jUbBAAAQBAJ\&pg=PT40\&dq=Die+Ehe+ist+eine+widersinnige+ Einrichtung $+\mathrm{F} \% \mathrm{C} 3 \% \mathrm{BCnfzehnj} \% \mathrm{C} 3 \% \mathrm{~A} 4 \mathrm{hrige}+\mathrm{Kind}+$ wird\&hl=pl\&sa=X\&ved $=0 \mathrm{CBsQ6AEw}$ AGoVChMI5JPm8t2DyAIVQ4wsCh0imQXd\#v=onepage\&q=Die\%20Ehe\%20ist\%20eine\%20wi dersinnige $\% 20$ Einrichtung $\% 20 \mathrm{~F} \% \mathrm{C} 3 \% \mathrm{BCnfzehnj} \% \mathrm{C} 3 \%$ A4hrige $\% 20 \mathrm{Kind} \% 20$ wird\&f=false, [dostęp: 19.07.2015].

56 W. Hain, R. Hain, Kaiserin Elisabeth und die historische Wahrheit, Norderstedt 2015, s. 53.

57 B. Wojciszke, Psychologia spoteczna, Warszawa 2013, s. 448.

${ }^{58}$ H. Andics, Kobiety Habsburgów, s. 195.

${ }^{59}$ R.K. Merton, Teoria socjologiczna i struktura społeczna, Warszawa 1982, s. 216. 
(przez kulturę należy w tym przypadku rozumieć „społeczność dworską" i towarzyszący jej ceremoniał). Podstawowym „przedmiotem” kontroli cesarzowej staje się więc jej ciało, a ściślej - różnorodne praktyki jego dyscyplinowania, zaawansowane do tego stopnia, by przy wzroście $172 \mathrm{~cm}$, zachować anorektyczną wręcz sylwetkę - 48 50 kg60 i „bajecznie wąską talię mniej niż 55 centymetrów"61. Swoisty kult piękna, który zawładnął życiem cesarzowej przybrał postać „urodowej fiksacji” podporządkowującej rytm dnia rytualnym czynnościom: ćwiczeniom fizycznym (w tym porannej gimnastyce, pieszym wycieczkom oraz jeździe konnej), restrykcyjnej diecie oraz zabiegom fryzjersko-kosmetycznym ${ }^{62}$. Specyfikę problemu żyjącej w XIX wieku cesarzowej Elżbiety doskonale egzemplifikuje wypowiedź współczesnego badacza Z. Melosika, który podkreśla, że

w sytuacji, gdy nie można panować nad światem zewnętrznym, kontrolowanie własnego ciała (niekiedy co do każdej kalorii i każdego pociągnięcia szminką) może dawać poczucie kontroli nad życiem, jakkolwiek nieprzemieszczona byłaby ta kontrola ${ }^{63}$.

Beznamiętne eksponowanie własnej urody (wydaje się, że bardziej w kontekście estetyki aniżeli seksualności) dodatkowo współwystępowało z neurotycznym wycofywaniem się Elżbiety ze świata społecznego (pogłębiającym się $\mathrm{z}$ upływem czasu) $\mathrm{w}$ bezpieczny świat iluzji wzniecanej poezją zarówno własną ${ }^{64}$, jak i - szczególnie ukochanego mistrza - Henryka Heinego. Chcąc "przeniknąć” przez grube mury własnej egzystencji, cesarzowa studiowała również liczne dzieła filozoficzne oraz uczyła się języków obcych (m.in. węgierskiego oraz greckiego). Wszystko to bezapelacyjnie wpisywało się w naznaczoną "motywem wędrownym” trajektorię jej życia. Nieustanne podróże stawały się - chwilowym przynajmniej - wentylem bezpieczeństwa, umożliwiającym ucieczkę ze znienawidzonego Wiednia65. Ze wspomnień Idy Sztáray (najbliższej damy dworu Elżbiety), opublikowanych w formie książki Aus den letzten Jahren der Kaiserin Elisabeth wynika, że jednym z wielu bliskich sercu cesarzowej miejsc na świecie była grecka wy-

${ }^{60}$ Więcej na temat BMI por. L. Cierpiałkowska, Psychopatologia, Warszawa 2014, s. 432. s. 224.

${ }^{61}$ J. des Cars, Kobiety, które zawładnęty Europa. Najpotężniejsze królowe, Warszawa 2014,

62 B. Hamann, Cesarzowa Elżbieta, s. 162-184.

63 Z. Melosik, Mass media, tożsamość i rekonstrukcje kultury wspótczesnej, [w:] Media - Edukacja - Kultura. W stronę edukacji medialnej, red. W. Skrzydlewski, S. Dylak, Poznań - Rzeszów 2012, s. 45 .

64 Por. Elisabeh von Österreich, Kaiserin Elisabeth von Österreich: Das poetische Tagebuch: (Komplettausgabe), 2013.

${ }^{65}$ B. Hamann, Cesarzowa Elżbieta, s. 385-393. 
spa Korfu, a ściślej pałac Achilleion wybudowany na jej życzenie ${ }^{66}$, o którym sama cesarzowa wypowiadała się niezwykle pochlebnie, wyrażając jednocześnie aprobatę wobec własnej izolacji: „To jest mój azyl, który w całości należy do mnie. Tutaj uciekam od wszelkich, przyziemnych rozważań"67. Interesujące wyjaśnienie owej społecznej regresji proponuje E. Fromm, zdaniem którego człowiek o skłonnościach neurotycznych podejmuje wprawdzie działania zmierzające do odzyskania własnej tożsamości, jednakże „próba zachowania swego indywidualnego 'ja' nie udaje się i zamiast twórczo to 'ja' wyrażać, szuka ratunku $\mathrm{w}$ zachowaniach neurotycznych i $\mathrm{w}$ ucieczce w świat fantazji”68. Doskonale obrazuje to również kwestia „niespecyficznych" relacji małżeńskich, które dla oziębłej seksualnie Elżbiety stały się kolejnym powodem do ucieczki. Jak sama stwierdziła: „Małżeństwo jest absurdalną instytucją, 15-letnie dziecko zostaje sprzedane, składa przysięgę, której nie rozumie, a potem przez 30 lat lub dłużej tego żałuje i nie może się wycofać" 69. Patową sytuację postanowiła zatem rozwiązać w sposób niezwykle kreatywny, oferując mężowi „przyjaciółkę do towarzystwa” - aktorkę, Katarzynę Schratt (jednakże niezwykle trudno jednoznacznie ustalić, jakie motywy nią kierowały: czy był to przejaw przejęcia kontroli nad sytuacją, czy raczej chęć zminimalizowania poczucia winy względem cesarza) ${ }^{70}$.

Reasumując, analiza biografii austriackich cesarzowych (arcyksiężniczek) wskazuje na różnorodne praktyki odzyskiwania kontroli (podejmowane w sposób mniej lub bardziej świadomy) będące - śmiem twierdzić przejawem walki o własną tożsamość. Niezbędne przy tym wydaje się uwzględnienie różnorodnych czynników, tak zewnętrznych (środowiskowych), jak i wewnętrznych (psychicznych), tworzących zarówno tło, jak i przestrzeń warunków, w których przyszło im funkcjonować (problem zmaskulinizowanej władzy Marii Teresy czy egocentrycznego wycofania Elżbiety Wittelsbach). Chcąc podkreślić doniosłość znaczenia owych komponentów, przywołam wypowiedź K. Vocelka, który podkreśla, że w trady-

${ }^{66}$ I. Sztáray, grófrö, Aus den letzten Jahren der Kaiserin Elisabeth, Wien 1909, s. 77.

${ }^{67}$ Rozważania cesarzowej coraz częściej oscylowały wokół wyobrażeń na temat jej własnej śmierci. Jak podaje jeden z ówczesnych tygodników "Österreichische Illustrierte Zeitung", cesarzowa (która w 1898 roku została zamordowana w Genewie) przed śmiercią miała wypowiedzieć następujące słowa: „Co się właściwie stało?” Odeszła więc prawdopodobnie w sposób o jakim marzyła - niespodziewany i nagły (E. Baron d'Albon, Unsere Kaiserin (Fragmente), "Österreichische Illustrierte Zeitung", 1898, 38, s. 6).

${ }^{68}$ E. Fromm, Ucieczka od wolności, Warszawa 1999, s. 140.

${ }^{69}$ G. Pirntke, Aufstieg und Fall der Kaiserin von Österreich, 2011.

${ }^{70}$ F. Charwath, Der Untergang einer mittelmäßigen Macht, die Großmacht sein wollte. Ein Lesebuch, Berlin-Kreuzberg 2011, s. 171. 
cyjnej historiografii (pozbawionej tych czynników) kobiety z dynastii Habsburgów (i nie tylko one) odegrały niewielką rolę, pozostając $\mathrm{w}$ cieniu gloryfikowanej, cesarskiej męskości. W jednopłaszczyznowych (androcentrycznych) biografiach „przedstawiane były one jako skromne, miłosierne i pobożne, zatem o ich udziale w życiu politycznym czy wpływie na mężów nie mogło być mowy"71. Deprecjacja rzeczywistych przymiotów i kompetencji intelektualnych stała się więc niejako naturalną przesłanką do zgeneralizowania obrazu roli, jaką realizowały. Współczesna analiza literatury przedmiotu oraz materiałów źródłowych pozwala na nowo odtworzyć czy wręcz zredefiniować historię tych kobiet, wzbogacając ją o socjologiczny i psychologiczny filtr. Uwzględniając tradycyjne (monolityczne) sposoby „wdrukowania” księżniczek do właściwej, cesarskiej (arcyksiążęcej) roli, możemy - stosując soczewkę indywidualizmu - przyjrzeć się nieco bardziej wnikliwie biografii każdej z nich. Bowiem, pomimo iż podlegały one tym samym, nieugiętym imperatywom, miały przecież - z racji różnic indywidualnych - odmienną konstrukcję psychiczną, która nadawała zindywidualizowaną barwę "całej siatce działań przypisanych do odpowiedniej [tutaj cesarskiej - przyp. A.J.] roli"72. Zatem, podjęcie próby odzyskania kontroli oraz sposobu jej definiowania przyjmowało odmienną formę, którą, mam nadzieję, udało się w niniejszym artykule ukazać. Przedłużeniem dokonanych przeze mnie rozważań staje się następująca konkluzja: przejawy walki kobiet-cesarzowych o własną tożsamość, choć niekiedy bardzo zawoalowane, pozwalają zrekonstruować spojrzenie na kwestie poczucia kontroli i sprawstwa, kreśląc odmienny, bardziej optymistyczny portret "świadomych" władczyń. Sądzę zatem, że warto porzucić tradycyjną koncepcję postrzegania owych kobiet w kontekście bezbarwnych, "socjalizacyjnych produktów”, bezwiednie poddających się podmuchom wiatru historii i spojrzeć na nie z perspektywy refleksyjnych podmiotów aktywnie kreujących własną tożsamościową przestrzeń (abstrahując od oceny efektywności owej kreacji).

\section{BIBLIOGRAFIA}

Andics H., Kobiety Habsburgów, Wrocław 1991.

Bankl H., Die kranken Habsburger. Befunde und Befindlichkeiten einer Herrscherdynastie, Wien 1998.

Baron d'Albon E., Unsere Kaiserin (Fragmente), "Österreichische Illustrierte Zeitung”, 1898, 38.

${ }^{71}$ K. Vocelka, Die Familien Habsburg und Habsburg-Lothringen: Politik, Kultur, Mentalität, Wien 2010, s. 103.

${ }^{72}$ E. Goffman, Spotkania. Dwa studia z socjologii interakcji, Kraków 2010, s. 69. 
Bechmann E., Die Frauen der Wittelsbacher: Ein Frauenbild vom Mittelalter bis in die Gegenwart, Norderstedt 2014.

Bogucka M., Gorsza płeć. Kobieta w dziejach Europy od antyku po wiek XXI, Warszawa 2005.

Cars des J., Kobiety, które zawładnęty Europa. Najpotężniejsze królowe, Warszawa 2014.

Charwath F., Der Untergang einer mittelmäßigen Macht, die Großmacht sein wollte. Ein Lesebuch, Berlin-Kreuzberg 2011.

Cierpiałkowska L., Psychopatologia, Warszawa 2014.

Fischer L., Schattenwürfe in die Zukunft: Kaiserin Elisabeth und die Frauen ihrer Zeit, Wien 1998.

Foucault M., Nadzorować i karać. Narodziny więzienia, Warszawa 1993.

Giddens A., Nowoczesność i tożsamość, Warszawa 2010.

Goffman E., Spotkania. Dwa studia z socjologii interakcji, Kraków 2010.

Grodziski S., Habsburgowie. Dzieje dynastii, Wrocław 1998.

Gromkowska-Melosik A., Edukacja i (nie)równość społeczna kobiet: studium dynamiki dostępu, Kraków 2011.

Gromkowska-Melosik A., Melosik Z., Tożsamość w społeczeństwie wspótczesnym: popkulturowe (re)interpretacje, Kraków 2012.

Hain W., Hain R., Kaiserin Elisabeth und die historische Wahrheit, Norderstedt 2015.

Hamann B., Cesarzowa Elżbieta, Warszawa 1999.

Judzińska A., Womanhood - contemporary paradoxes of equality and exclusion, Journal of Gender and Power, 2014, 2(2).

King G., Woolmans S., Zabić arcyksięcia, Kraków 2014.

Melosik Z., Mass media, tożsamość i rekonstrukcje kultury wspótczesnej, [w:] Media - Edukacja Kultura. W stronę edukacji medialnej, red. W. Skrzydlewski, S. Dylak, Poznań - Rzeszów 2012.

Merton R.K., Teoria socjologiczna i struktura społeczna, Warszawa 1982.

Mühlbach L., Joseph II. And his Cort. An Historical Novel, przekł. A DeV. Chaudron, New York 1867.

Elisabeh von Österreich, Kaiserin Elisabeth von Österreich: Das poetische Tagebuch: (Komplettausgabe), 2013.

Pirntke G., Aufstieg und Fall der Kaiserin von Österreich, 2011, https://books.google. $\mathrm{pl} /$ books?id=0jUbBAAAQBAJ\&pg=PT40\&dq=Die+Ehe+ist+eine+widersinnige+Einr ichtung $+\mathrm{F} \% \mathrm{C} 3 \% \mathrm{BCnfzehnj} \% \mathrm{C} 3 \%$ A4hrige + Kind +wird\&hl=pl\&sa=X\&ved=0CBs

Q6AEwAGoVChMI5JPm8t2DyAIVQ4wsCh0imQXd\#v=onepage\&q=Die $\%$ 20Ehe $\% 20$ ist \%20eine \%20widersinnige \% 20Einrichtung \%20F\%C3\%BCnfzehnj\%C3\%A4hrige \% 20 Kind \%20wird\&f=false, [dostęp: 19.07.2015].

Poznaniak W., Teorie uczenia się społecznego jako model normalnego i zaburzonego funkcjonowania jednostki oraz grupy, [w:] Społeczna psychologia kliniczna, red. H. Sęk, Warszawa 2000.

Sellés-Ferrando X., Spanisches Österreich, Wien 2004.

Strauss J., Zemsta Nietoperza, „Kuplety Adeli” - akt III.

Sztáray grófrö, I., Aus den letzten Jahren der Kaiserin Elisabeth, Wien 1909.

Titkow A., Kategoria ptci kulturowej jako instrumentarium badawcze i źródło wiedzy o społeczeństwie, [w:] Gender w społeczeństwie polskim, red. K. Slany, J. Struzik, K. Wojnicka, Kraków 2011.

Wojciszke B., Psychologia społeczna, Warszawa 2013. 
Yonan M.E., Empress Maria Theresa and the Politics of Habsburg Imperial Art, Pensylwania State 2011.

Vocelka K., Die Familien Habsburg und Habsburg-Lothringen: Politik, Kultur, Mentalität, Wien 2010.

Zamojska E., Dażenia emancypacyjne kobiet - równość w dyskursie feministycznym, Pampaedia: Leszczyńskie Studia Humanistyczne 2004, 1. 